\title{
A review on nutritional composition, health benefits, and technological interventions for improving consumer acceptability of camel meat: an ethnic food of Middle East
}

\author{
Waqas N. Baba ${ }^{1,2+}$, Nuzhat Rasool ${ }^{1 \dagger}$, M. Selvamuthukumara ${ }^{3}$ and Sajid Maqsood ${ }^{2 *}$ (D)
}

\begin{abstract}
Camel meat is an ethnic food consumed across the arid regions of Middle East and North-East Africa. It can be a potential alternative red meat for human consumption worldwide. Camel meat is nutritionally as good as any conventional meat source, in fact has an edge over beef or lamb due to its low intramuscular fat, low cholesterol content, and high iron content. Camel meat quality is a function of age, breed, and type of muscle consumed. Various techniques such as aging, low-temperature storage, and pre-treatment with antioxidants improve the quality and shelf life of camel meat. Active packaging and fermentation are promising techniques to improve consumer acceptance and shelf-life of camel meat. Very limited research is available about the use of novel pretreatments, packaging, and processing techniques that can improve the consumer acceptability of camel meat. Due to restricted use of camel meat and its products to ethnic regions, a review highlighting the nutritional potential and strategies to improve the quality of camel meat and its products may enhance its global acceptance as an alternative source of red meat.
\end{abstract}

Keywords: Camel meat, Composition, Medicinal value, Quality, Packaging, Processing

\section{Introduction}

Traditional meat products from camel meat have been consumed across various arid regions of the world such as Middle East, North Africa, and Mediterranean from time immemorial. In these regions, consumption of various traditional camel meat products is an important part of cuisine during family and religious celebrations and its certain parts such as hump and liver are considered as delicacies [1, 2]. Various camel meat-based ethnic products consumed across the world (Fig. 1) include Guedid, Khliaa ezir, Fregate, Tarfa-Gara, Cachir, Maynama (Algeria, Morocco), Tidkit, Khlii, Mkila, Tehal/tehane (Morocco), Madfoon (United Arab Emirates, Saudi Arabia), Soudjouk,

\footnotetext{
* Correspondence: sajid.m@uaeu.ac.ae

tWaqas N. Baba and Nuzhat Rasool contributed equally to this work.

${ }^{2}$ Deparment of Food Science, College of Agriculture and Veterinary Medicine, United Arab Emirates University, Al Ain 15551, United Arab Emirates
} Full list of author information is available at the end of the article
Suçuk, Nakanek, Pastirma, and Merdouma (Egypt) [3]. Different methods to produce such traditional meat products involve drying, fermentation, salting, and cooking or their combination with the main aim to improve the palatability and shelf life of camel meat [4].

Despite of marginal contribution to average meat production of the world and a decrease in the nomadic population, camel population has increased at higher rate in comparison to other species such as sheep, cattle, and horses [5]. Camel meat production has grown to 14 tonnes in 2018 that corresponds to $6.4 \%$ increase against previous year [6] and its processing into various ethnic and modern-day food items (sausages, burgers, and patties) is also showing considerable growth [3, 7-11]. Moreover, camel meat is considered as an appropriate food source to meet the growing needs for meat in developing countries, especially for low-income population

(c) The Author(s). 2021 Open Access This article is licensed under a Creative Commons Attribution 4.0 International License, which permits use, sharing, adaptation, distribution and reproduction in any medium or format, as long as you give

appropriate credit to the original author(s) and the source, provide a link to the Creative Commons licence, and indicate if changes were made. The images or other third party material in this article are included in the article's Creative Commons licence, unless indicated otherwise in a credit line to the material. If material is not included in the article's Creative Commons licence and your intended use is not permitted by statutory regulation or exceeds the permitted use, you will need to obtain permission directly from the copyright holder. To view a copy of this licence, visit http://creativecommons.org/licenses/by/4.0/ 


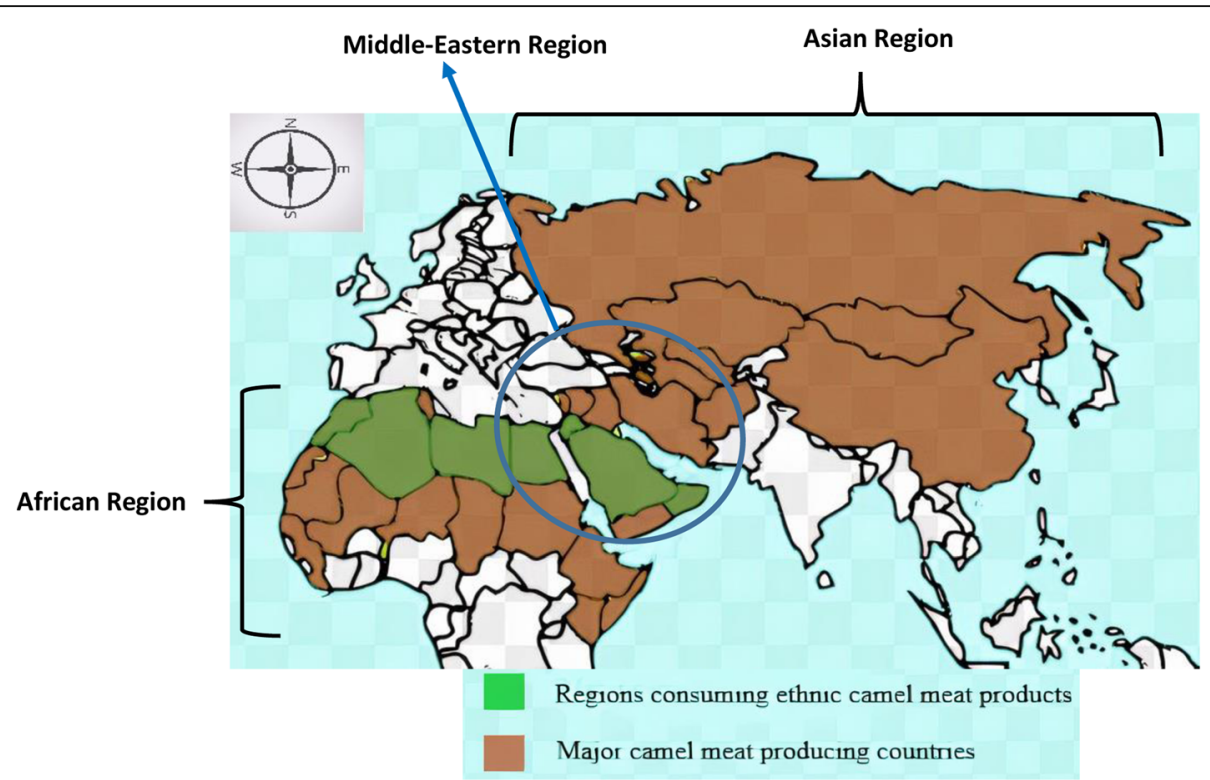

Fig. 1 Major camel meat producing and camel meat consuming countries

groups due to its resilient nature to survive in harsh conditions and high carcass yield. Also, camels grow well and may live to reach a weight of about $650 \mathrm{~kg}$ producing carcass weight ranging from 55 to $70 \%$ as such making camel meat as good as beef in terms of carcass yield $[6,12]$. Apart from being a rich source of protein, its consumption has also been associated with numerous health benefits. Camel meat consumption has been used in Chinese and nomadic traditional medicine probably due to the presence of various bioactive components such as carnosine and angiotensin I-converting enzyme (ACE)-inhibitors [13, 14]. Moreover, with issues like climate change severely affecting the traditional livestock production, rearing camels for meat production holds potential as future protein source and may offer a viable alternative to red meat [15]. However, despite its nutritional and health benefits, camel meat is yet to find an organized market which might be due to limited awareness about nutritional potential as well as scattered information about the methods for improving its overall quality.

A compilation of existing literature related to various methods for improving the quality and shelf life of camel meat has not been reviewed to the best of our knowledge. Therefore, this review attempts to explore the nutritional composition, health benefits of camel meat, as well as various technological interventions such as packaging, pre-treatment, and processing to improve its quality and consumer acceptance. This review will be helpful for researchers and highlight the potential for global marketability of camel meat and its products.
Relevant research articles were obtained from PubMed, Scopus, and Google Scholar databases. The relevant studies were identified by using keywords and Boolean operators: "camel meat" AND ("composition" OR "health benefits" OR "processing" OR "active packaging" OR "fermentation") AND ("shelf life" OR "” OR "quality" OR "storage" OR "polyphenols" OR "plant extracts" OR "inorganic acids" OR "curing" OR "sensory analysis" OR "acceptability"). Manual research was also conducted to identify any relevant studies in those databases.

\section{Nutritional composition of camel meat Macronutrients}

In general, meat is a rich source of macro as well as micronutrients and provides essential amino acids, fats, and vitamins essential for human growth. Camel lean meat contains about $78 \%$ water, $19 \%$ protein, $3 \%$ fat, and $1.2 \%$ ash with a small amount of intramuscular fat, which renders it a healthy food for humans (Table 1). Mohammed et al. [23] reported higher moisture, mineral, vitamin, and protein content in camel meat than mutton, beef and chicken, while the fat and cholesterol content was lower. The proximate composition of camel meat has been reviewed and reported to be well within this range [13].

Camel meat has been reported for its low-fat content (1.1 to $10.0 \%$ ) [24] in comparison with other meat sources such as veal [25], bovine, and sheep [26]. In a comparative study among different meat sources camel meat (1.51\%) was reported to have significantly lower fat 
Table 1 Comparison of composition of camel meat with meat from other species

\begin{tabular}{lllllll}
\hline Species & Moisture (\%) & Protein (\%) & Fat (\%) & Ash (\%) & Muscle & References \\
\hline Camel & 71.0 & 21.4 & 4.4 & 1.1 & Longissimus & Kadim et al. [16] \\
Llama & 73.9 & 23.1 & 0.51 & 2.43 & Longissimus & Cristofanelli [17] \\
Alpaca & 73.6 & 23.3 & 0.49 & 2.5 & Longissimus & Cristofanelli [17] \\
Beef & 71.5 & 21.5 & 5.5 & 0.9 & Longissimus & Mills et al. [18] \\
Sheep & 68.9 & 21.0 & 8.5 & 1.2 & Longissimus & Sen et al. [19] \\
Goat & 76.5 & 20.8 & 1.6 & 0.87 & Longissimus & Marinova et al. [20] \\
Broiler & 75.5 & 22.4 & 1.5 & 0.6 & PM & Castellini et al. [21] \\
Duck & 76.8 & 21.0 & 1.68 & 1.0 & PM & Baeza et al. [22] \\
\hline PM & & & & &
\end{tabular}

$P M$ pectoralis major

content in comparison to beef $(6.83 \%)$ and mutton (4.56\%) [23]. Kadim et al. [16] also reported the fat content of camel meat (2.8\%) significantly lower than beef (7.8\%) confirming the leaner composition of camel meat in comparison with beef. Similar results were reported by Elgasim and Alkanhal [27] who reported a fat content of $4.7 \%$ in beef that was significantly lower in comparison with camel meat fat content (2.6\%). Biceps femoris samples of camel meat (1.2\%) showed a lower fat content in comparison to mutton (1.8\%) and beef (18.1\%) samples [28]. The fat content of different portions of camel and cattle meat such as biceps femoris, triceps brachii, and longissimus dorsi showed significantly lower fat content in the camel irrespective of age and gender [2]. Moreover, camel meat has been reported to have lower cholesterol content in comparison to other meat sources [13]. The cholesterol content in camel meat was reported at $57.56 \mathrm{mg} / 100 \mathrm{~g}$ that was significantly lower than that of beef $(74.5 \mathrm{mg} / 100 \mathrm{~g})$ [29]. In a comparative study, similar results of lower cholesterol in camel meat $(139 \mathrm{mg} / 100 \mathrm{~g})$ in comparison with lamb (196 $\mathrm{mg} / 100 \mathrm{~g})$ and beef $(206 \mathrm{mg} / 100 \mathrm{~g})$ were previously reported [30].

Thus, the negative implication of meat consumption on human health due to high amount of saturated fat content is not applicable in case of camel meat that can make camel meat a preferred meat type across the world. Moreover, the high content of polyunsaturated fatty acids with lower levels of cholesterol adds more advantages to camel meat consumption [13, 31].

Camel meat is also a good source of protein with the amount varying from 20 to $23 \%$ [32, 33]. Bekhit et al. [13] reported the protein content of camel meat was in the range $18.2-23.7 \%$. These protein contents are similar to values previously reported by Dawood and Alkanhal [34], but lower than the values previously reported by Elgasim and Alkanhal [27]. The protein content of camel meat makes it a good source of high-quality protein in arid and semiarid regions.

\section{Micronutrients}

Camel meat is a rich source of both micro and macroelements and is comparable to other meat types such as veal, beef, and lamb [27, 33]. Camel meat contains the highest potassium content followed by phosphorous, sodium, and calcium, respectively. Ulmer et al. [35] reported that the mineral and vitamin content of muscles from the shoulder of a camel as calcium $6.5 \mathrm{~g} / 100 \mathrm{~g}$, magnesium $23.6 \mathrm{~g} / 100 \mathrm{~g}$, potassium $293 \mathrm{~g} / 100 \mathrm{~g}$, sodium $58.2 \mathrm{~g} / 100 \mathrm{~g}$, zinc $3.4 \mathrm{~g} / 100 \mathrm{~g}$, iron $2.1 \mathrm{~g} / 100 \mathrm{~g}$, copper $0.2 \mathrm{~g} / 100 \mathrm{~g}$, thiamine $0.12 \mathrm{~g} / 100 \mathrm{~g}$, riboflavin $0.18 \mathrm{~g} / 100$ $\mathrm{g}$, pyridoxine $0.25 \mathrm{~g} / 100 \mathrm{~g}$, and alpha-tocopherol $0.61 \mathrm{~g} /$ $100 \mathrm{~g}$.

In general, camel meat quality characteristics are like beef especially when slaughtered young $[16,33,36]$. The authors reported camel meat to be a rich source of iron $(45.5 \mathrm{mg} / 100 \mathrm{~g})$ in comparison to beef $(1.8 \mathrm{mg} / 100 \mathrm{~g})$, mutton $(4.05 \mathrm{mg} / 100 \mathrm{~g})$, and poultry $(0.4 \mathrm{mg} / 100 \mathrm{~g})$. Reza Gheisari et al. [2] illustrated that for most of the factors studied, fresh camel, and cattle meat was similar, apart from fat and ash contents which were lower in camel meat $(P<0.05)$. The amino acid and mineral contents of camel meat are often higher than that of beef (Table 2), probably due to lower intramuscular fat levels [16]. Camel meat has significantly higher levels of vitamins C, B3, B6, B12, D, and E in comparison with beef, mutton, and poultry [23]. Gheisari et al. [40] reported higher amounts of glutathione oxidase and catalase in camel meat in comparison to beef and chicken.

Thus, the nutritional superiority of camel meat (Table 1) due to its lower fat content compared to many other meat species can be considered as an important feature by health-conscious consumers and may be exploited as a marketing strategy of camel meat [34].

\section{Variation in nutritional composition of camel meat Effect of age}

The effect of slaughter age on meat composition is important as it affects the quality characteristics of meat that ultimately affect the consumer acceptance. Meat of 
Table 2 Amino acid composition ( $\mathrm{g} / 16 \mathrm{~g} \mathrm{~N}$ ) of meat from different species

\begin{tabular}{|c|c|c|c|c|c|}
\hline & Camel $^{a}$ & Buffalo $^{b}$ & Harp seal $^{c}$ & Beef $^{d}$ & Chicken $^{\mathrm{e}}$ \\
\hline \multicolumn{6}{|c|}{ Essential amino acids } \\
\hline Lysine & 8.45 & 9.7 & 8.72 & 9.12 & 8.96 \\
\hline Threonine & 4.4 & 4.75 & 4.53 & 4.64 & 4.16 \\
\hline Valine & 5.16 & 4.51 & 5.8 & 5.28 & 4.8 \\
\hline Methionine & 2.41 & 4.51 & 1.64 & 2.72 & 2.40 \\
\hline Isoleucine & 5.23 & 1.31 & 4.58 & 5.12 & 4.64 \\
\hline Leucine & 8.41 & 7.24 & 7.44 & 8.00 & 7.52 \\
\hline Phenylalanine & 4.24 & 4.23 & 4.57 & 4.48 & 4.48 \\
\hline Histidine & 4.33 & 3.33 & 5.01 & 3.20 & 3.04 \\
\hline \multicolumn{6}{|c|}{ Nonessential amino acids } \\
\hline Arginine & 7.38 & 1.42 & 6.21 & 6.72 & 6.24 \\
\hline Aspartic acid & 9.09 & 7.62 & 8.23 & 9.60 & 9.12 \\
\hline Serine & 3.63 & 3.30 & 3.98 & 4.48 & 4.00 \\
\hline Glutamic acid & 16.91 & 12.51 & 11.5 & 17.28 & 16.48 \\
\hline Proline & 5.39 & 3.60 & 3.89 & 5.12 & 4.16 \\
\hline Glycine & 5.95 & 4.50 & 4.47 & 5.60 & 4.82 \\
\hline Tyrosine & 3.23 & 3.19 & 2.85 & 3.84 & 3.52 \\
\hline Alanine & 6.25 & 3.24 & 5.88 & 6.40 & 5.76 \\
\hline Cystine & & 1.27 & 0.87 & 1.28 & 1.28 \\
\hline Tryptophan & 0.60 & & 1.20 & 1.28 & 1.12 \\
\hline
\end{tabular}

${ }^{a}$ Dawood and Alkanhal [34]; ${ }^{\mathrm{b}}$ Ziauddin et al. [37]; ${ }^{\mathrm{c}}$ Shahidi and Synowiecki [38]; d,e Paul and Southgate [39]

younger animals is usually preferred over meat of older animals due to affects related to tenderness and colour [41]. The chemical composition of camel meat is significantly affected by the age of the camel $[33,42,43]$. Ibrahim et al. [44] also reproted a significant increase in the fat content while a non-significant change in the protein content of meat from Sudanese camel of two age groups viz 3-4 years and 6-8 years. Fat content of muscles increased significantly from $92 \%$ in younger camels ( $<1$ year) to $97 \%$ in older camels ( $>3$ years). Also, the amount of saturation in camel meat fat was reported to decrease with increase in age [42]. Cholesterol content of older camels was reported to be significantly higher in 26-month-old camels $(150 \mathrm{mg} / 100 \mathrm{~g})$ in comparison with 8 -month-old camels $(135 \mathrm{mg} / 100 \mathrm{~g})$ [30]. Increase in the cholesterol content of camels with increase in age has been attributed to increase in fat content rather than increase in the synthesis of cholesterol [13]. Kadim et al. [33] studied the chemical composition of longissimus thoracis muscle of Omani male camels from three different age groups and reported a decrease in protein content while an increase in the fat content with increase in the age of camels. It was observed that the moisture and ash content of camel meat is not affected by age. Camel meat from older animals had a higher mineral content
( $\mathrm{Ca}, \mathrm{Mg}, \mathrm{Na}, \mathrm{K}$, and $\mathrm{P}$ ) than meat from younger animals. Asli et al. [43] also reported a significant increase in the iron content of camel meat with an increase in age. Heavy non-essential metals such as $\mathrm{Pb}$ and $\mathrm{Cd}$ are natural constituents of meat and were higher in older animals (6-8 years) than younger ones. These minerals are regarded as contaminants if present in high levels. They are toxic and tend to accumulate in animal body [45]. Asli et al. [43] reported significantly higher cobalt and zinc concentrations in muscle during the first 6 months of the year.

Thus, camel meat from animals of younger age (1-3 years) should be preferred considering the tenderness as well as lower fat and cholesterol content during initial years of growth.

\section{Effect of muscle portion}

The nutritional composition of camel meat varies significantly depending on the type of muscle studied. Kadim et al. [46] found significant differences in moisture, fat, protein, mineral, saturated, and unsaturated fatty acid contents between muscles from 10 dromedary camel carcasses. Suliman et al. [12] reported significant difference in protein, fiber, and ash content of camel meat belonging to longissimus lumborum, biceps femoris, and semimembranosus. However, Babiker \& Yousif [47] reported that three muscles (longissimus, semitendinosus, and triceps brachii) of camel had same protein, fat, and moisture content but had different ash content. According to Herrmann \& Fisher [48], different portions of camel vis. shoulder, loin, and topside had different nutritional composition. The shoulder and topside had the high protein $(77-78 \%)$ and low fat $(1.1 \%)$, while the loin had the low protein $(73 \%)$ and high fat percentage (6.6\%). Authors also reported a significant variation in the vitamin and mineral content of camel meat from different anatomical sites on the carcass. However, Kadim et al. [42] found that the fat of the hump and abdomen has comparable fatty acid compositions. Gulzhan Raiymbek et al. [49] also reported significantly lower levels of phosphorus, magnesium, sodium, and potassium in longissimus thoraces than semitendinosus, infraspinatus, triceps brachii, biceps femoris, and semimembranosus muscles. A difference in the mineral content of camel meat and camel liver was also reported [43]. Thus, overall nutritional composition of camel meat is significantly affected by the muscle type studied.

\section{Effect of breeds}

The chemical composition of camel meat is reported to vary with variation in the breeds. There is a marked variation in fat content between species, while water content is almost similar (70-77\% moisture) which is higher than conventional meats [33, 34, 50]. Suliman et al. [12] 
reported variation in the chemical composition of camel meat in different camel breeds. The authors reported a lower fat and ash content in Baladi Saudi and Somali breeds than Pakistani breeds with no significant difference in the protein content. However, contrary results suggesting a non-significant difference in the nutritional composition of camel meat from four different camel species of Saudi Arabia have also been reported [32].

\section{Characterization of camel meat fat and proteins}

The conversion of muscle to meat is achieved through a series of biochemical changes converting muscle into meat that is affected by the composition of meat [51]. These biochemical changes are followed by various compositional changes involving protein and lipid fraction that affect the acceptability of meat [52]. These compositional changes produce various degradation products such as aldehydes, sulfides, free amino acid, and biogenic amines such as spermidine, cadaverine, tyramine, etc., that depends on the lipid and amino acid profile of meat [53]. The fatty acid and amino acid content and type vary depending upon the type of meat source (Table 2). For example, lamb and pork were reported to have lesser contents of essential amino acids such as valine, lysine, and leucine in comparison to beef [54]. Thus, a detailed understanding of the compositional analysis of camel fat and proteins can help food technologists in devising new methods for improving its shelf life and consumer acceptability.

Camel meat contains both saturated as well as unsaturated fatty acids with high levels of unsaturated fatty acids than saturated ones [31, 32]. Rawdah et al. [31] reported twenty-two fatty acids from camel meat containing good amount of unsaturated fatty acids such as oleic acid (18.93\%) and linoleic acid (12\%). Maqsood et al. [52] reported palmitic acid (C16:0) as a dominant fatty acid followed by stearic acid (C18:0) and oleic acid (C18: $1 \mathrm{n}-9$ ). Content of total saturated fatty acid (SFA) and unsaturated fatty acids were 58.46 and $41.5 \mathrm{mg} / 100 \mathrm{~g}$. Among unsaturated fatty acids, authors reported a high content of oleic acid (32.725) and linoleic acid (3.806). Similar results were reported by Mohammed et al. [23]. The higher content of saturated fatty acids can be due to the age of camel slaughtered since saturation increases with age [42]. Similar results were previously reported $[46,55]$. The authors also reported that in camel meat, semitendinosus had the highest saturated fatty acids, while infraspintus muscle showed lowest saturated fatty acid content. Also, semimembranosus and biceps femoris had the highest MUFA and PUFA suggesting fatty acid composition depends on the type of muscle studied, respectively. Mohammed et al. [23] compared different amounts of fatty acids in beef, mutton, and chicken with camel meat and reported lower levels of fatty acids such as palmitic acid in camel meat. Similar results were reported by Khezrian et al. [56].

Furthermore, camel meat was reported to have a higher peroxide value and TBARS value while a lower iodine value in comparison with chicken and beef. A higher peroxide value and TBARS value indicates less stable fat, while iodine value is a measure of unsaturation in fats [57]. Higher lipid oxidation in camels has been attributed to high heme content in camel meat [58].

The major proteins identified in camel meat are myosin heavy chain, $\mathrm{C}$-protein, alpha-actinin, tropomyosin, and actin [52]. Camel meat has a higher content of essential amino acids such as histidine, leucine, and isoleucine than other meat sources. Lysine and leucine are the most abundant essential amino acids in camel meat. The tryptophan concentration was low in camel meat compared with other meat sources (Table 2). Camel meat has higher methionine and leucine content compared with other red meats with a higher amino acid index than other red meats. This suggests camel meat is a source of high and superior quality protein than red meat [58, 59]. Mohammed et al. [23] reported higher levels of methionine, histidine, isoleucine, lysine, and threonine in comparison with conventional meat sources. There was no significant effect of the slaughter age on the amino acid composition of camel meat; however, a difference of up to $166.7 \%$ was recorded with the type of cut [46]. The total collagen amount was higher in camel longissimus dorsi muscle as compared with triceps brachii and semitendinosus muscles, probably because of the morphological conditions to stabilize the hump attached to the longissimus dorsi [47]. Camel meat is regarded as a superior source of non-essential amino acids such as glutamic and aspartic acids [23, 56]. However, contradictory reports about the quantity of alanine in camel meat have been reported with evidences showing higher as well as lower levels of alanine in comparison with conventional meat sources [46].

\section{Health benefits of camel meat consumption}

In general, meat is a rich source of protein and various bioactive compounds that impart several health benefits [60]. Amino acids and bioactive compounds in meat and connective tissue prevent sarcopenia and maintain blood pressure through ACE inhibitory components. The nucleotides and nucleosides present in meat are essential for maintaining the internal environment of human cells [61]. Meat-derived bioactive peptides have various health benefits that include antihypertensive, antithrombotic, anticancer, antioxidant, and immunomodulatory properties [62]. Meat contains polyunsaturated fatty acids [63] such as $\alpha$-linolenic acid that are known to play a vital role in the prevention of cardiovascular diseases, 
brain development in children, and other metabolic effects [64-66].

Medicinal values of camel meat were reviewed that suggested most camel meat consumers believe it is a healthy option during the dry season during which cattle are usually infected with various zoonotic diseases $[67,68]$. This belief probably originated from the historical use of the animal organs as well as meat in the remedial formulation by early Muslim scholars: Al-Kindi, Al-Tabari, and Al-Qazwimi. Camel meat and offal such as liver is believed to have medicinal effects and are often eaten raw which is not advisable because of the possible risk of zoonotic infection like plague [69]. Studies and medical research have proved that camel meat is superior to other kinds of meat and is distinguished from other animals by the fact that the percentage of its intramuscular fat declines as the animal gets older [70]. This quality, only found in camels, makes their meat less fatty, so its consumption is healthy and recommended for weight loss. Several epidemiological studies linked health problems such as obesity and hypertension to the consumption of high saturated fat and cholesterol intake of animal products [71]. This has led to the concern that total dietary fat intake should be restricted by replacing red meat consumption with white meat. The growing evidence of low cholesterol and fat content in camel meat can potentially support its healthiness as a better alternative to the high fat and cholesterol-rich meats such as mutton and beef [72]. Low levels of saturated fat in the diet are important for avoiding atherosclerosis because of their effect on plasma cholesterol levels. Low intake of saturated fatty acids and cholesterol is important for the control of obesity and hypercholesterolemia and to decrease the risk of cancer [73]. Health organizations have recommended reductions in total fat intake, particularly saturated fatty acids, and increase in the consumption of polyunsaturated fatty acids which are considered beneficial to human health due to anticarcinogenic, anti-atherogenic, and immune-modulating properties [74]. This renders the camel meat, with its low fat and cholesterol content and high unsaturated fatty acids, a healthy food. Moreover, camel meat is believed by Somali and Indian people to have remedial effects for as many as 13 different diseases, including hyperacidity, hypertension, pneumonia, and respiratory diseases and also tends to be an aphrodisiac [67]. The antihypertensive potential of camel meat was attributed to its ACE inhibitors found at a concentration of $65.1-72.5 \%$ [14]. However, no in vivo studies exist that could authenticate the medicinal effect of camel meat suggesting plenty of scope for researchers to explore this field.
Furthermore, the low bioaccumulation of pesticides in camel meat [75] is particularly of interest because many American countries still face the problem with organochlorine abuse in terms of the inventory of obsolete pesticides or the lack of control of their use, which consequently leads to health problems [76]. Camels are, however, reared in arid regions where the use of pesticides is limited resulting in lower amounts of pesticides in camel meat. However, lower pesticide residues in camel meat observed by Sallam \& Morshedy [75] might be due to the lack of exposure to organochlorines rather than natural lower bioaccumulation.

Camel meat is believed to cure seasonal fever sciatica, and shoulder pain, as well as for removing freckles by placing hot meat slices on freckled areas [68]. Camel meat soup was used to cure corneal opacity and to strengthen eyesight [14]. Camel meat is used to ease haemorrhoidal pains, and the hump fat is used to remove tapeworm; dried camel lung used to be prescribed as a cure for asthma especially if taken with honey [77]. Camel meat is also known for its high percentage of iron, one of the important components of blood haemoglobin which helps to reduce the risk of anaemia. Camel meat contains carnosine $(181.7 \mathrm{mg} / 100 \mathrm{~g})$, a dipeptide known for its antioxidant properties and is converted to another bioactive compound called anserine. Carnosine contains alanine and histidine found in high concentrations in brain tissue where it is reported to function as a putative neurotransmitter [14]. The levels are reported to vary between different camel muscle principally due to varied metabolic activity [78]. Camel meat is reported to be a rich source of carnitine and taurine that are known for various health benefits such as conjugation of bile acids and regulation of calcium signaling [68].

\section{Strategies for enhancing the quality and shelf-life of camel meat \\ Aging}

Aging is a complex process that improves various quality attributes of meat over time that depend on physicochemical parameters, rate of acidification, changes in osmotic pressure, and proteolytic and glycolytic enzymes. An aging period of 7 days at $2-3{ }^{\circ} \mathrm{C}$ was reported to significantly improve camel meat quality $[12,46]$. Increased drip loss and reduced water-holding capacity due to a decrease in the sarcomere length on day 5 and day 7 were reported [79]. Different studies illustrated that aging enhances the muscles' tenderness [77]. Increased tenderness during aging has been attributed to postmortem decrease in $\mathrm{pH}$ and proteolytic processes and increased myofibrillar fragmentation index [12]. 


\section{Low-temperature storage}

Low-temperature storage has been widely used for reducing the growth of spoilage and pathogenic bacteria/microbes in meat. A decrease in temperature reduces the rate of reaction resulting in a decrease in the metabolic activities of cells. Storage at refrigeration temperature (4 ${ }^{\circ} \mathrm{C}$ ) reduced the growth of spoilage-causing microorganisms, E. coli O157:H7 and Salmonella spp., and increased the shelf life of ground camel meat $[9,10]$. Increased protein extractability, solubility, TCA-soluble peptides, and drip loss during storage suggest proteolysis and degradation of structural proteins (Fig. 2) during refrigerated storage of camel meat [52]. This observation was complemented by the SDS-PAGE pattern [80] depicting noticeable degradation of myosin heavy chain, C-protein, alpha-actinin, as well as tropomyosin bands on day 9 of storage. Camel meat has been reported as more tender than beef after an aging period of 7 days and attributed it to higher protease activity as indicated by the degradation of Z-line and production of $30 \mathrm{kDa}$ fragments (a degradation product of troponin $\mathrm{T}$ ) [80]. The authors reported that in beef, the $30-\mathrm{kDa}$ component was absent up to 3 days of storage and then started to appear. The appearance of a $30-\mathrm{kDa}$ band at 3 days of storage in camel meat also implied that this meat had a higher degree of proteolysis [80]. An increase in lipid oxidation as indicated by an increase in the peroxide value (PV) and thiobarbituric acid reactive substances (TBARS) during storage of camel meat has been reported [52, 57]. Camel meat was found to be brighter (higher $b^{*}$ value), tenderer, and more stable to oxidative damage (lesser formation of thiobarbituric acid) than beef during aging periods of 72 and $168 \mathrm{~h}$ [36]. A significant interaction effect of aging with the breed as well as the type of muscle on various quality parameters of camel meat has been reported affecting quality especially camel meat tenderness [12]. The authors also reported that aging had no adverse effects on sensory analysis parameters such as colour, flavour, tenderness, juiciness, and acceptability values. A significant decrease in enzyme catalase and glutathione peroxidase enzyme during refrigerated storage of camel meat for 4 days was reported [40]. Also, the peroxide value and TBARS values were reported to increase in camel meat. A significant decrease in the heme content and a corresponding decrease in the $b$ value of camel meat during a 9-day refrigerated storage of camel meat was reported [52]. Reza Gheisari et al. [2] reported a decrease in water-holding capacity, while drip loss and acid value increased during the frozen storage of camel and cattle meat. However, there was no difference between the studied parameters of camel and cattle meat at the end of storage.

Changes in the protein pattern of camel meat packed under three different packaging systems during 14 days of refrigerated storage were studied by Maqsood et al. [81] (Fig. 3). The detectable protein bands in fresh camel meat were myosin heavy chain $(200 \mathrm{kDa}), \mathrm{C}$-protein, actinin, tropomyosin, actin $(44 \mathrm{KDa})$, a-tropomyosin, b-

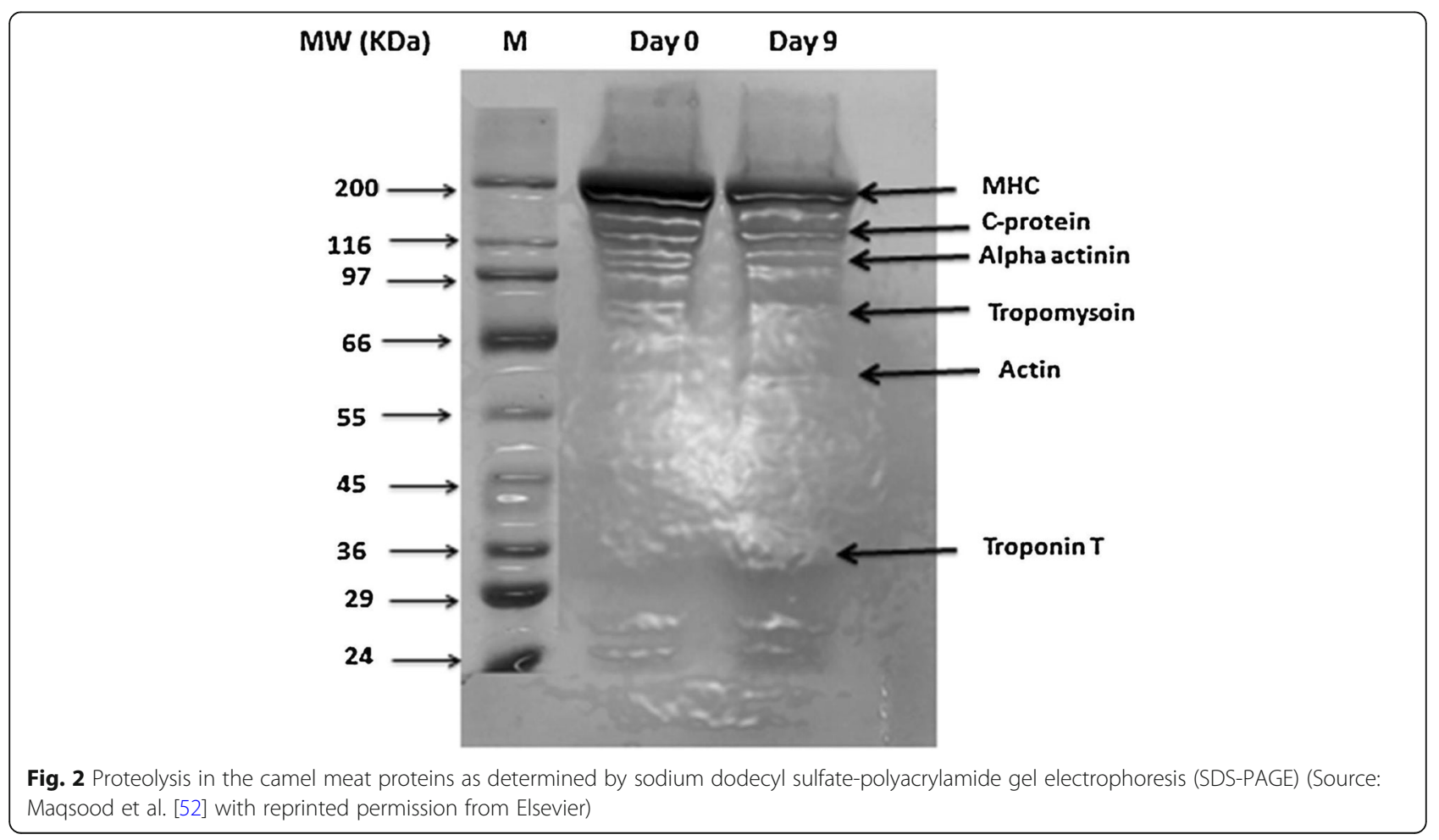




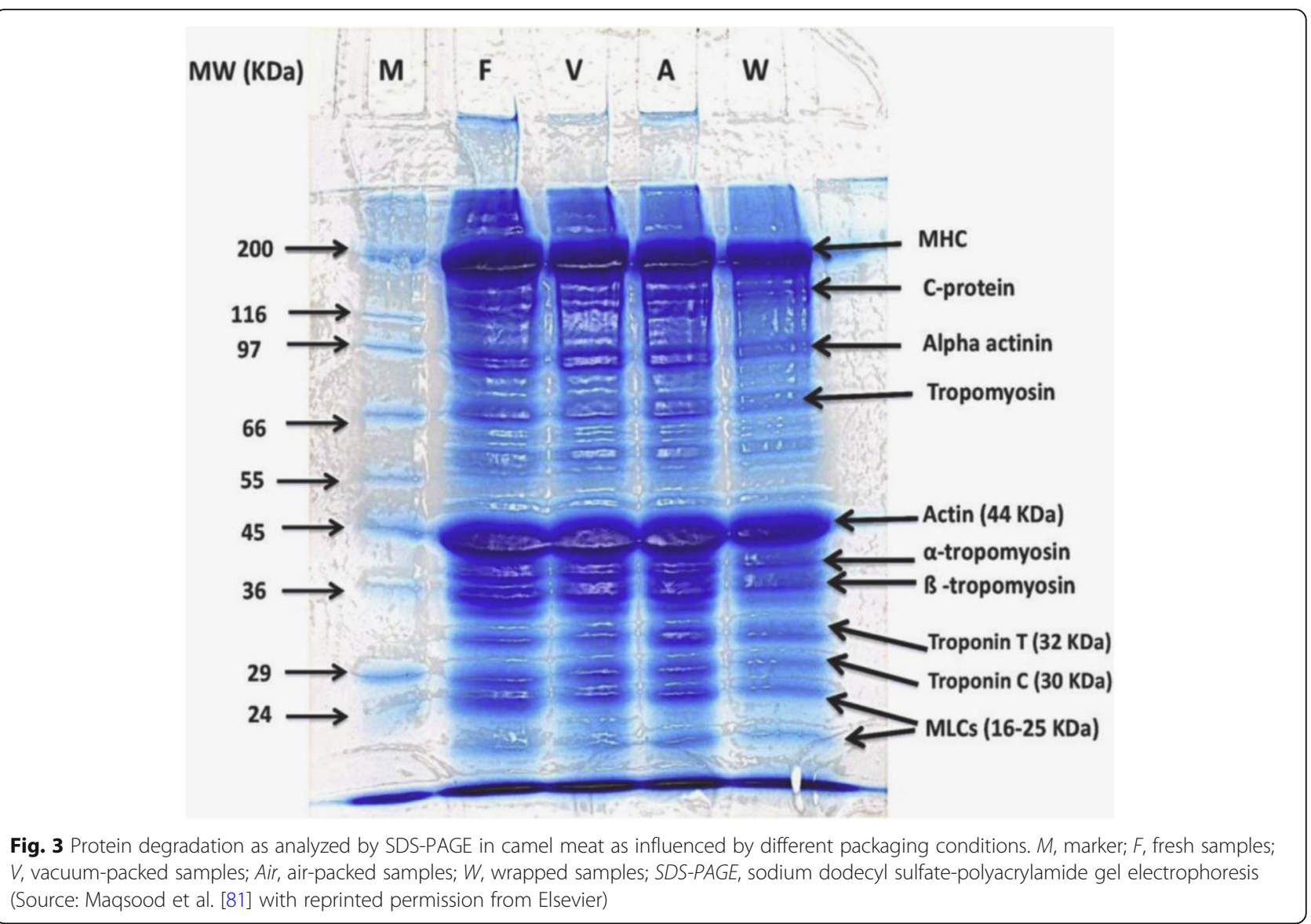

tropomyosin, troponin $\mathrm{T}(32 \mathrm{KDa})$, troponin $\mathrm{C}(30$ $\mathrm{KDa})$, and myosin light chain (16-25 KDa). During the storage in different packaging conditions at refrigerated temperature for 14 days, different proteins in the camel meat underwent degradation to different degrees as depicted in Fig. 3. Myosin heavy chain, C-protein, alphaactinin, as well as tropomyosin bands showed a noticeable degradation on day 14 of storage in case of wrapped sample and a mild degradation in air-packaged samples. The degradation of different protein bands in wrapped and air-packed camel meat was mainly due to enzymatic degradation of proteins caused by the bacterial load. Thus, a huge lacuna exists pertaining to the storage of camel meat using novel methods of meat storage.

\section{Effect of pretreatments}

Different pretreatments have been reported to improve meat quality characteristics by reducing the microbial load, lipid peroxidation, shear value, and improving colour retention in meats.

Addition of plant extracts containing various bioactive compounds have been used to improve the shelf life of food products [82]. Djamel et al. [83] reported addition of Olea europaea subsp. laperrinei improved the shelf life of fresh camel meat by reducing lipid peroxidation with highest score for sensory acceptability by sensory panelists. Polyphenolic compounds due to their antioxidant potential have been extensively used for mitigating lipid peroxidation in camel meat. Maqsood et al. [84] reported better quality retention in the camel meat with a significant decrease in psychotropic and mesophilic bacterial counts in camel meat by the intervention of phenolic compounds especially tannic acid and catechins than gallic acid and caffeic acid (Fig. 4). Gheisari et al. [40] used garlic in biceps femoris muscles of camel and reported a significant decrease in lipid oxidation parameters such as peroxide value and TBA values over a storage period of 14 days. Fresh garlic was reported to impart antioxidant and antimicrobial effects at $40 \mathrm{~g} / \mathrm{kg}$ in camel meat. Shahbazi et al. [85] also reported that essential oil from Mentha spicata at concentrations of $0.5 \%$ and $1 \%$ improved preservation of camel meat without developing any unfavourable organoleptic properties. Incorporation of ginger improved the physicochemical and sensory properties of camel burgers [86]. The authors reported a significant increase in various sensory parameters such as tenderness, juiciness, flavour, appearance, and overall acceptability. Incorporation of gingerol resulted in a significant decrease in the total plate count, total psychrophilic counts, total enterobacteriaceae 

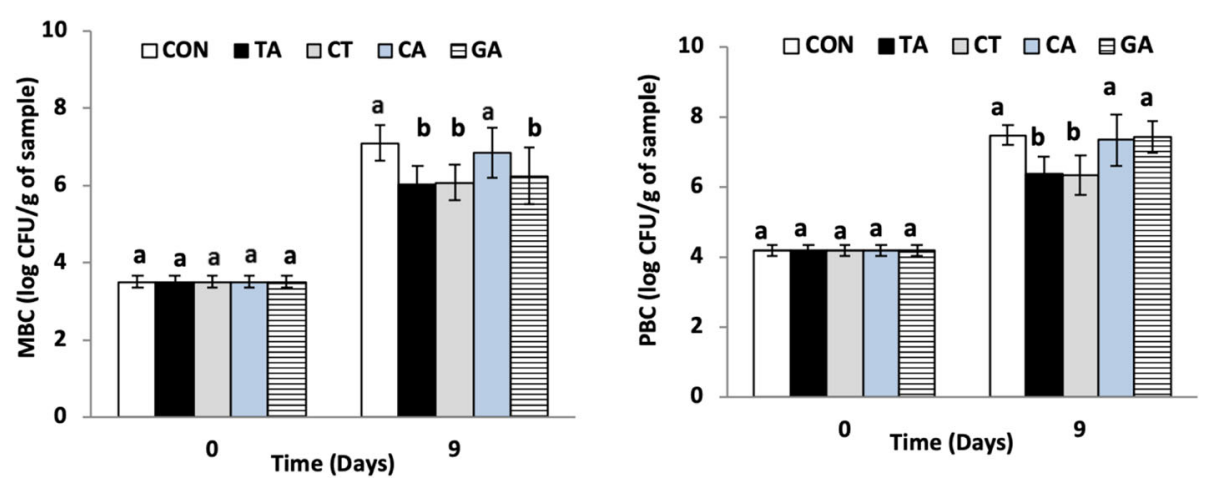

Fig. 4 Effect of different phenolic compounds on (a) mesophilic bacterial count (MBC) and (b) psychrophilic bacterial count (PBC) in camel meat during 9 days of refrigerated storage. Bars represent the standard deviation $(n=9)$. Different letters on the bar within the same storage time denote the significant differences $(P<0.05)$. Key: CON: samples without any treatment; TA: tannic acid-treated samples; $C T$ : catechin-treated samples; CA: caffeic acid-treated samples; GA: gallic acid-treated samples (Source: Maqsood et al. [84] with Reprinted permission from Elsevier)

count, number of coliforms, and total mold counts as well as various biogenic amines in a dose-dependent manner in camel muscle and offal (kidney, rumen, lungs) [87]. Biogenic amines such as tyramine, putrescine, and cadaverine are spoilage indicators [88] that measure the level of hygiene related to meat and meat products [89]. A synergistic effect in reducing the microbial load was reported when gingerol was used in combination with nisin. The authors reported that 2.5\% concentration of each nisin and gingerol decreased the level of cadaverine, tyramine, and spermidine to belowdetectable levels. Furthermore, addition of chitosan in combination with citrox was reported to significantly improve various sensory parameters such as colour, odour, flavour, taste, as well as overall acceptability measured using a hedonic scale [90].

Curing is one of the widely used pretreatments in meat [51] that involves the application of nitrates and nitrites. Curing salts help in the retention of colour, improvement of taste, and retard microbial growth. Curing resulted in lesser susceptibility of camel meat towards lipid oxidation by preventing a decrease in the glutathione peroxidase levels [91]. Fallah et al. [92] reported that irradiation of fresh camel meat at 1.5 and $3.0 \mathrm{kGy}$ accompanied by refrigeration storage-enhanced product shelf life by 15 and 21 days without any significant detrimental effects on its sensory acceptability accessed by sensory panelists, respectively. Improvement in the shelf life of camel meat by 6 weeks using various irradiation doses of 0-6 kGy was also previously reported [93]. Irradiation did not cause any significant changes in the chemical composition or lipid oxidation of camel meat and can be an important method for improving the shelf life of camel meat by limiting the growth of various pathogenic and spoilage bacteria. Electrically stimulated camel meat at $90 \mathrm{~V}$ and $14 \mathrm{~Hz}$ was reported to have lower ultimate $\mathrm{pH}$ and shear force values as well as higher expressed juice and myofibrillar fragmentation [94, 95]. Al-Sheddy et al. [50] treated fresh camel meat with different organic acids and reported that sodium acetate alone or in combination with bifidobacteria maintained $\mathrm{pH}$ level and extended microbial shelf life (> 12 days). Furthermore, the sensory analysis of the treated fresh camel meat samples showed better retention of surface colour with reduced off-odour development in comparison with untreated samples during storage. The use of salts such as $\mathrm{NaCl}$ and $\mathrm{KCl}$ have been reported as an effective strategy for improving the oxidative stability of camel meat due to its effects on catalase and glutathione peroxidase [40]. The use of calcium chloride infusions $(250 \mathrm{mM}$ injected at a rate of $5 \%)$ was reported to reduce the share value of camel meat [96] which is attributed to activation of calpains by $\mathrm{Ca}^{2+}$ resulting in myofibrillar solubilization thereby improving the textural properties of camel meat. Evidently, various pretreatments as well as curing significantly enhance various quality as well as sensory parameters of camel meat and its products.

\section{Effect of packaging and processing}

Very limited literature is available regarding novel packaging methods as an intervention for improving shelf life of camel meat. Maqsood et al. [81] studied the effect of different packaging material on the quality of camel meat. Vacuum packaging was identified as a viable means for preventing protein degradation, lipid oxidation, and limiting microbial growth in comparison with camel meat samples packaged in cling wrap. Vacuum-packaged samples showed better colour retention as indicated by higher redness (a) values that was attributed to better retention of heme in vacuum-packaged samples. Sensory analysis also revealed higher results for overall acceptability and odour of vacuum-packaged samples. Active packaging films based on nanomontmorillonite-chitosan and 
nanomontmorillonite-carboxymethyl cellulose loaded with different concentrations of Ziziphora clinopodioides essential oil were reported to enhance the overall quality of minced meat samples. The active-packaged samples were reported to have reduced TBARS and peroxide values as well as received higher scores by sensory panellists for odour, colour, and overall acceptability [56]. Djenane et al. [83] reported that synergistic use of various biopreservation techniques such as refrigeration, modified atmospheric packaging along with the use of nisin improved the shelf life without any adverse effects on the sensory attributes of camel meat.

Fermentation is a natural processing technique used for enhancing the nutritional and nutraceutical content and shelf life of different meat types depending upon the starter culture used [97]. Various strains such as Lactobacillus sakei, Staphylococcus xylosus, and $S$. carnosus have been safely used in meat products [98, 99]. Competitive exclusion and production of inhibitors such as nisin limit growth of spoilage and pathogenic microorganism. There is an increase in the shelf life of minced camel meat products using various lactic acid bacteria cultures isolated from naturally fermented foodstuffs [8]. The improvement in shelf life was attributed to the antibacterial effect of selected cultures. Camel meat sausages were fermented with Lactobacillus casei and L. paracasi and evaluated for various quality characteristics after $0.10,20,30,40$, and 45 days of storage [11]. The authors reported that sausages fermentated with $L$. paracasei had superior physicochemical, microbial, and sensory characteristic. Enhanced flavour, texture, and overall acceptability of sausages was attributed to various catabolic products generated from carbohydrates, lipids, and proteins by microbial starter culture, while lactic acid produced by the lactic bacteria was reported to promote the colour. The generation of more intense flavour components in a fermented sausage (sucuk) in which beef was replaced with camel meat was also reported [7]. Furthermore, the hydrolytic enzymes from microbes generate bioactive peptides that are known to impart various health benefits [100]. Ayyash et al. [101] studied the effect of fermentation using Lactococcus lactis KX881782 on bioactivities of fermented beef and camel sausages. Camel sausage showed significantly lower lipid oxidation indicated by significantly lower TBARS values in camel sausages. Furthermore, ACE inhibiting potential, antidiabetic potential and antioxidant activity of fermented camel were superior in sausage containing camel fermented meat. Fermentation is associated with reduction of biogenic amines that are potentially unsafe nitrogenous compounds generated from decarboxylation of some amino acids [102]. Camel meat sausage containing a mixed starter culture of $L$. sakei, S. xylosus, and S. carnosus were reported to have significantly lesser concentration of biogenic amines [98].

Among different processing methods, microwaving, roasting, and braising, the highest cook loss and share value were seen in microwaved samples. Several changes such as disarrangement of sarcomere units, shortage of sarcomere length, and physical disruption in myofibril units in roasted samples were observed [103].

\section{Conclusion and future research}

Camel meat is a rich source of various macro and micronutrients making it nutritionally as good as any conventional meat sources. The nutritional quality of camel meat varies with age, breed, and type of muscle. In addition to high levels of various essential amino acids, camel meat contains both saturated as well as unsaturated fatty acids. Camel meat is low in fat and cholesterol making it a preferred choice of meat for health-conscious consumers. The nutritional aspects and health benefits of camel meat can be utilized as a marketing strategy for enhancing its consumer acceptance. Camel meat quality as well as shelf life can be improved by using various pretreatments such as the use of polyphenolics, curing, aging, and packaging. Among various technological interventions, active packaging and fermentation have plenty of scope in enhancing the quality and consumer acceptance of camel meat. Further research should be directed to implement innovative processing and preservation technologies for development of diverse products with superior consumer acceptance. Furthermore, studies directed towards the development of appropriate packaging of camel meat is needed for the shelf-life extension which will promote the export of camel meat to the countries where camels are not reared.

\section{Acknowledgments \\ United Arab Emirates University is acknowledged for funding a research grant on camel meat (UAEU-31F024).}

\section{Authors' contributions}

The authors read and approved the final manuscript.

\section{Funding}

Authors are thankful to United Arab Emirates University for funding this research through research grants (UAEU-NRF: 31 F024 and UPAR: 31F078).

\section{Availability of data and materials}

Not applicable

\section{Declarations}

Competing interests

The authors declare no competing interests. 


\section{Author details}

'Department of Food Science and Technology, University of Kashmir, Srinagar 190006, India. ${ }^{2}$ Deparment of Food Science, College of Agriculture and Veterinary Medicine, United Arab Emirates University, Al Ain 15551, United Arab Emirates. ${ }^{3}$ Department of Food Science \& Technology, Hindustan Institute of Technology \& Science, Chennai, India.

\section{Received: 4 February 2021 Accepted: 11 July 2021}

\section{Published online: 16 August 2021}

\section{References}

1. Saparov G, Annageldiyev, O. Meat productivity of the camel Arvana breed and ways to increase it. In: B. Faye and P. Esenov (Eds), Proceedings of the International Workshop on "Desertification combat and food safety : the added value of camel producers", Ashkabad (Turkmenistan), 19-22 april 2004. In : Vol. 362 NATO Sciences Series, Life and Behavioural Sciences. IOS press Publ., Amsterdam (The Netherlands), pp. 224-227.

2. Reza Gheisari H, Aminlari M, Shahram SS. A comparative study of the biochemical and functional properties of camel and cattle meat during frozen storage. Veterinarski arhiv. 2009;79(1):51-68.

3. Gagaoua M, Boudechicha H-R. Ethnic meat products of the North African and Mediterranean countries: an overview. J Ethnic Foods. 2018;5(2):83-98. https://doi.org/10.1016/j.jef.2018.02.004.

4. Farouk MM, Bekhit AE-D. 12 Processed camel meats. Camel Meat Meat Products. 2012;91:186.

5. Faye B. The camel new challenges for a sustainable development. Trop Anim Health Prod. 2016;48(4):689-62 https://doi.org/10.1007/s11250-0160995-8.

6. Kadim I, Al-Amri I, Kindi A, Mbaga M. Camel meat production and quality: a review. J Camel Pract Res. 2018;25(1):9. https://doi.org/10.5958/2277-8934.2 018.00002 .4

7. Kargozari M, Moini S, Basti AA, Emam-Djomeh Z, Ghasemlou M, Martin IR, et al. Development of Turkish dry-fermented sausage (sucuk) reformulated with camel meat and hump fat and evaluation of physicochemical, textural, fatty acid and volatile compound profiles during ripening. LWT Food Sci Technol. 2014;59(2):849-58. https://doi.org/10.1016/j.lwt.2014.05.033.

8. Kalalou I, Faid M, Touhami AA. Extending shelf life of fresh minced camel meat at ambient temperature by Lactobacillus dlbrueckii subsp. delbrueckii. Electron J Biotechnol. 2004;7(3):05-6.

9. Osaili TM, Al-Nabulsi AA, Dhanasekaran DK, Hasan F, Rao S, Fatima H, et al. Growth behaviour and thermal inactivation of E. coli O157: H7 and Salmonella spp. in ground lean camel meat. Int J Food Microbiol. 2020;316: 108423.

10. Osaili TM, Hasan F, Dhanasekaran DK, Obaid RS, Al-Nabulsi AA, Rao S, et al. Thermal inactivation of Escherichia coli 0157: H7 strains and Salmonella spp. in camel meat burgers. LWT. 2020;120:108914.

11. Hasan Hussein F, Razavi SH, Emam DZ. Evaluation of physicochemical, sensorial and microbiological attributes of fermented camel sausages. Iran J Chem Chem Eng (IJCCE). 2019;38(2):171-81.

12. Suliman GM, Alowaimer AN, Hussein EOS, Ali HS, Abdelnour SA, El-Hack MEA, et al. Chemical composition and quality characteristics of meat in three one-humped camel (Camelus dromedarius) breeds as affected by muscle type and post-mortem storage period. Animals. 2019;9(10):834. https://doi.org/10.3390/ani9100834

13. Bekhit AE-D, Farouk MM. 13 Nutritive and health value of camel meat. Camel Meat Meat Products. 2013;205. https://doi.org/10.1079/978178064101 0.0205 .

14. Kadim IT, Sahi ABA. Health aspects of camel meat: a review of literature. Adv Anim Vet Sci. 2018;6(7):271-2.

15. Zarrin M, Riveros JL, Ahmadpour A, de Almeida AM, Konuspayeva G, VargasBello-Pérez $\mathrm{E}$, et al. Camelids: new players in the international animal production context. Trop Anim Health Prod. 2020:1-11.

16. Kadim IT, Mahgoub O, Al-Marzooqi W. Meat quality and composition of longissimus thoracis from Arabian camel (Camelus dromedaries) and Omani beef: a comparative study. J Cam Sci. 2008;1(1):37-47.

17. Cristofanelli S, Antonini M, Torres D, Polidori P, Renieri C. Meat and carcass quality from Peruvian llama (Lama glama) and alpaca (Lama pacos). Meat Sci. 2004;66(3):589-93. https://doi.org/10.1016/S0309-1740(03)00174-8.

18. Mills EW, Comerford JW, Hollender R, Harpster HW, House B, Henning WR. Meat composition and palatability of Holstein and beef steers as influenced by forage type and protein source. J Anim Sci. 1992;70(8):2446-51. https:// doi.org/10.2527/1992.7082446x.

19. Sen AR, Santra A, Karim SA. Carcass yield, composition and meat quality attributes of sheep and goat under semiarid conditions. Meat Sci. 2004; 66(4):757-63. https://doi.org/10.1016/S0309-1740(03)00035-4.

20. Marinova P, Banskalieva V, Alexandrov S, Tzvetkova V, Stanchev H. Carcass composition and meat quality of kids fed sunflower oil supplemented diet. Small Rumin Res. 2001;42(3):217-25. https://doi.org/10.1016/S0921-4488(01 00245-0.

21. Castellini C, Mugnai C, Dal BA. Effect of organic production system on broiler carcass and meat quality. Meat Sci. 2002;60(3):219-25. https://doi. org/10.1016/S0309-1740(01)00124-3.

22. Baeza E, Dessay C, Wacrenier N, Marche G, Listrat A. Effect of selection for improved body weight and composition on muscle and meat characteristics in Muscovy duck. Br Poult Sci. 2002;43(4):560-8. https://doi. org/10.1080/0007166022000004471.

23. Mohammed $\mathrm{HHH}$, Jin G, Ma M, Khalifa I, Shukat R, Elkhedir AE, et al. Comparative characterization of proximate nutritional compositions, microbial quality and safety of camel meat in relation to mutton, beef, and chicken. LWT. 2020;118:108714. https://doi.org/10.1016/j.lwt.2019.108714.

24. Eskandari $\mathrm{MH}$, Majlesi M, Gheisari HR, Farahnaky A, Khaksar Z. Comparison of some physicochemical properties and toughness of camel meat and beef. J Appl Anim Res. 2013:41(4):442-7. https://doi.org/10.1080/09712119.2013.792735.

25. Nikmaram P, Yarmand MS, Emamjomeh Z. Effect of cooking methods on chemical composition, quality and cook loss of camel muscle (Longissimus dorsi) in comparison with veal. Afr J Biotechnol. 2011;10(51):10478-83.

26. Sahraoui N, Dotreppe O, Errahmani MB, Boudjenah S, Baaissa B, Guetarni D, et al. Caractérisation des acides gras de la viande cameline en Algérie. Cahiers de Nutrition et de Diététique. 2014;49(5):231-4. https://doi.org/10.1 016/j.cnd.2014.03.007.

27. Elgasim EA, Alkanhal MA. Proximate composition, amino acids and inorganic mineral content of Arabian camel meat: comparative study. Food Chem. 1992;45(1):1-4. https://doi.org/10.1016/0308-8146(92)90002-J.

28. Elsharawy NT, Ahmad AM, Abdelrahman HA. Quality assessment of nutritional value and safety of different meat. J Food Microbiol Saf Hyg. 2018;3:132.

29. Mohammed SAA. A study of cholesterol concentrations of camel meat and beef. Int J Agric Innov Res. 2019;7(4):397-401.

30. Abu-Tarboush HM, Dawood AA. Cholesterol and fat contents of animal adipose tissues. Food Chem. 1993;46(1):89-93. https://doi.org/10.1016/03088146(93)90082-Q.

31. Rawdah TN, El-Faer MZ, Koreish SA. Fatty acid composition of the meat and fat of the one-humped camel (Camelus dromedarius). Meat Sci. 1994;37(1): 149-55. https://doi.org/10.1016/0309-1740(94)90151-1.

32. Al-Owaimer AN, Suliman GM, Sami AS, Picard B, Hocquette J-F. Chemical composition and structural characteristics of Arabian camel (Camelus dromedarius) m. longissimus thoracis. Meat Sci. 2014;96(3):1233-41. https:// doi.org/10.1016/j.meatsci.2013.10.025.

33. Kadim IT, Mahgoub O, Al-Marzooqi W, Al-Zadjali S, Annamalai K, Mansour $\mathrm{MH}$. Effects of age on composition and quality of muscle longissimus thoracis of the Omani Arabian camel (Camelus dromedaries). Meat Sci. 2006; 73(4):619-25. https://doi.org/10.1016/j.meatsci.2006.03.002.

34. Dawood AA, Alkanhal MA. Nutrient composition of Najdi-camel meat. Meat Sci. 1995;39(1):71-8. https://doi.org/10.1016/0309-1740(95)80008-5.

35. Ulmer K, Herrmann K, Fischer A. Meat products from camel meat. Milk and meat from the camel. 2004:137-228.

36. Shariatmadari R, Kadivar M. Postmortem aging and freezing of camel meat (a comparative study); 2006.

37. Ziauddin KS, Mahendrakar NS, Rao DN, Ramesh BS, Amla BL. Observations on some chemical and physical characteristics of buffalo meat. Meat Sci. 1994;37(1):103-13. https://doi.org/10.1016/0309-1740(94)90148-1.

38. Shahidi F, Synowiecki J, Dunajski E, Chong X. Nonprotein nitrogen compounds in harp seal (Phoca groenlandica) meat. Food Chem. 1993;46(4): 407-13. https://doi.org/10.1016/0308-8146(93)90013-6.

39. Paul AA, Southgate DAT. McCance and Widdowson's. Food Composition Tables in Translation, vol. 129; 1978.

40. Gheisari HR, Motamedi $\mathrm{H}$. Chloride salt type/ionic strength and refrigeration effects on antioxidant enzymes and lipid oxidation in cattle, camel and chicken meat. Meat Sci. 2010;86(2):377-83. https:/doi.org/10.1016/j.meatsci.2010.05.020.

41. Bakhsh A, Hwang Y-H, Joo S-T. Effect of slaughter age on muscle fiber composition, intramuscular connective tissue, and tenderness of goat meat 
during post-mortem time. Foods. 2019;8(11):571. https://doi.org/10.3390/ foods8110571.

42. Kadim IT, Mahgoub O, Al-Maqbaly RS, Annamalai K, Al-Ajmi DS. Effects of age on fatty acid composition of the hump and abdomen depot fats of the Arabian camel (Camelus dromedarius). Meat Sci. 2002;62(2):245-51. https:// doi.org/10.1016/50309-1740(01)00254-6.

43. Asli M, Azizzadeh M, Moghaddamjafari A, Mohsenzadeh M. Copper, iron, manganese, zinc, cobalt, arsenic, cadmium, chrome, and lead concentrations in liver and muscle in Iranian camel (Camelus dromedarius). Biol Trace Elem Res. 2020;194(2):390-400. https://doi.org/10.1007/s12011-01 9-01788-2.

44. Ibrahim GA, Nour IA, Kadim IT. Effect of age on quality characteristics and composition of muscles of Sudanese camel (Camelus dromedarius). Journal of Camel Practice and Research. 2015;22(2):209-16. https://doi.org/10. 5958/2277-8934.2015.00033.8

45. Ruiter A. Contaminants in meat and meat products. Dev Meat Sci. 1985;3: 185-220.

46. Kadim IT, Al-Karousi A, Mahgoub O, Al-Marzoogi W, Khalaf SK, Al-Maqbali RS, et al. Chemical composition, quality and histochemical characteristics of individual dromedary camel (Camelus dromedarius) muscles. Meat Sci. 2013; 93(3):564-71. https://doi.org/10.1016/j.meatsci.2012.11.028.

47. Babiker SA, Yousif OK. Chemical composition and quality of camel meat. Meat Sci. 1990;27(4):283-7. https://doi.org/10.1016/0309-174 O(90)90066-F.

48. Herrmann K, Fisher A. Methods for hygienic slaughter of camels. Milk and Meat from the Camel: Handbook on Products and Processing Swiss Federal Institute of Technology, Zurich, Switzerland; 2004. p. 89-135.

49. Raiymbek G, Faye B, Serikbayeva A, Konuspayeva G, Kadim IT. Chemical composition of infraspinatus, triceps brachii, longissimus thoraces, biceps femoris, semitendinosus, and semimembranosus of Bactrian (Camelus bactrianus) camel muscles. Emirates J Food Agric. 2013;25(4):261-6. https:// doi.org/10.9755/ejfa.v25i4.15492.

50. Al-Sheddy I, Al-Dagal M, Bazaraa WA. Microbial and sensory quality of fresh camel meat treated with organic acid salts and/or bifidobacteria. J Food Sci. 1999;64(2):336-9. https://doi.org/10.1111/j.1365-2621.1999.tb15895.x.

51. Lawrie RA. Meat science. 3rd ed. Oxford: Pergamon Press; 1979.

52. Maqsood S, Abushelaibi A, Manheem K, Kadim IT. Characterisation of the lipid and protein fraction of fresh camel meat and the associated changes during refrigerated storage. J Food Compos Anal. 2015;41:212-20. https:// doi.org/10.1016/j.jfca.2014.12.027.

53. Triki M, Herrero AM, Jiménez-Colmenero F, Ruiz-Capillas C. Quality assessment of fresh meat from several species based on free amino acid and biogenic amine contents during chilled storage. Foods. 2018;7(9):132. https://doi.org/10.3390/foods7090132.

54. Ahmad RS, Imran A, Hussain MB. Nutritional composition of meat, In: Meat Sci. Nutr. 2018;61:10.5772. https://doi.org/10.5772/intechopen.77045.

55. Raiymbek G, Faye B, Kadim IT, Serikbaeva A, Konuspayeva G. Comparative fatty acids composition and cholesterol content in Bactrian (Camelus bactrianus) and dromedary camel (Camelus dromedarius) meat. Trop Anim Health Prod. 2019;51(7):2025-35. https://doi.org/10.1007/s112 50-019-01894-2.

56. Khezrian A, Shahbazi Y. Application of nanocompostie chitosan and carboxymethyl cellulose films containing natural preservative compounds in minced camel's meat. Int J Biol Macromol. 2018;106:1146-58. https://doi. org/10.1016/j.jibiomac.2017.08.117.

57. Gheisari HR. Correlation between acid, TBA, peroxide and iodine values, catalase and glutathione peroxidase activities of chicken, cattle and camel meat during refrigerated storage. Veterinary World. 2011;4(4):153-7.

58. Seong PN, Cho SH, Park KM, Kang GH, Park BY, Moon SS, et al. Characterization of chicken by-products by mean of proximate and nutritional compositions. Korean J Food Sci Anim Resour. 2015;35(2):179-88. https://doi.org/10.5851/kosfa.2015.35.2.179.

59. Raiymbek G, Kadim I, Konuspayeva G, Mahgoub O, Serikbayeva A, Faye B. Discriminant amino-acid components of Bactrian (Camelus bactrianus) and Dromedary (Camelus dromedarius) meat. J Food Compos Anal. 2015;41:194200. https://doi.org/10.1016/j.jfca.2015.02.006.

60. Migdał W, Živković B. Meat: From functional food to diseases of modern civilization. Biotechnol Anim Husbandry. 2007;23(5-6-1):19-31.

61. Young JF, Therkildsen M, Ekstrand B, Che BN, Larsen MK, Oksbjerg N, et al. Novel aspects of health promoting compounds in meat. Meat Sci. 2013; 95(4):904-11. https://doi.org/10.1016/j.meatsci.2013.04.036.
62. Pighin D, Pazos A, Chamorro V, Paschetta F, Cunzolo S, Godoy F, et al. A contribution of beef to human health: a review of the role of the animal production systems. Sci World J. 2016;2016:1-10. https://doi.org/10.1155/201 6/8681491.

63. Valencak TG, Gamsjäger L, Ohrnberger S, Culbert NJ, Ruf T. Healthy n-6/n-3 fatty acid composition from five European game meat species remains after cooking. BMC research notes. 2015;8(1):273. https://doi.org/10.1186/s13104015-1254-1.

64. Garcia PT, Casal JJ. Effect of dietary plant lipids on conjugated linoleic acid (CLA) concentrations in beef and lamb meats. Soybean-Bio-Active Compounds. 2013. p. 135-59.

65. Salter AM. Dietary fatty acids and cardiovascular disease. Animal. 2013;7(s1): 163-71. https://doi.org/10.1017/S1751731111002023.

66. Garcia PT. Metabolism of a-linolenic acid (ALA) in meat animals. Soybean Nutr. 2011. p. 349-68.

67. Kurtu MY. An assessment of the productivity for meat and the carcase yield of camels (Camelus dromedarius) and of the consumption of camel neat in the Eastern region of Ethiopia. Trop Anim Health Prod. 2004;36(1):65-76. https://doi.org/10.1023/B:TROP.0000009520.34657.35.

68. Abrhaley A, Leta S. Medicinal value of camel milk and meat. J Appl Anim Res. 2018;46(1):552-8. https://doi.org/10.1080/09712119.2017.1357562.

69. Saeed AAB, Al-Hamdan NA, Fontaine RE. Plague from eating raw camel liver. Emerg Infect Dis. 2005;11(9):1456-7. https://doi.org/10.3201/eid1109.050081.

70. Shareha A, Shekal A, Shagen A, Biala A, editors. The effect of age on fat deposition in longissimus dorsi muscle (between 12th-13th rib) of camels and compared with those in beef and sheep. 2009.

71. Biesalski HK. Meat as a component of a healthy diet-are there any risks or benefits if meat is avoided in the diet? Meat Sci. 2005;70(3):509-24. https:// doi.org/10.1016/.j.meatsci.2004.07.017.

72. Schönfeldt HC, Gibson N. Changes in the nutrient quality of meat in an obesity context. Meat Sci. 2008;80(1):20-7. https://doi.org/10.1016/j.meatsci.2 008.05.025.

73. Chizzolini R, Zanardi E, Dorigoni V, Ghidini S. Calorific value and cholesterol content of normal and low-fat meat and meat products. Trends Food Sci Technol. 1999;10(4-5):119-28. https://doi.org/10.1016/ S0924-2244(99)00034-5.

74. Mulvihill B. Ruminant meat as a source of conjugated linoleic acid (CLA). Nutr Bull. 2001;26(4):295-9. https://doi.org/10.1046/j.1467-3010.2001.00179.x.

75. Sallam Kl, Morshedy AEMA. Organochlorine pesticide residues in camel, cattle and sheep carcasses slaughtered in Sharkia Province. Egypt Food Chem. 2008;108(1):154-64. https://doi.org/10.1016/j.foodchem.2007.10.066.

76. Daba D, Hymete A, Bekhit AA, Mohamed AMI, Bekhit AE-DA. Multi residue analysis of pesticides in wheat and khat collected from different regions of Ethiopia. Bull Environ Contam Toxicol. 2011;86(3):336-41. https://doi.org/10.1 007/s00128-011-0207-1.

77. Kadim IT, Mahgoub O, Mbaga M. Potential of camel meat as a nontraditional high quality source of protein for human consumption. Anim Front. 2014;4(4):13-7. https://doi.org/10.2527/af.2014-0028.

78. Dunnett M, Harris RC. High-performance liquid chromatographic determination of imidazole dipeptides, histidine, 1-methylhistidine and 3methylhistidine in equine and camel muscle and individual muscle fibres. J Chromatogr B Biomed Sci Appl. 1997;688(1):47-55. https://doi.org/10.1016/ S0378-4347(97)88054-1.

79. Abdelhadi O, Babiker S, Hocquette J-F, Picard B, Durand D, Faye B. Effect of ageing on meat quality of the one humped camel (Camelus dromedarius). Emirates J Food Agric. 2013;25(2):150-8. https://doi.org/10, 9755/ejfa.v25i2.15402.

80. Soltanizadeh N, Kadivar M, Keramat J, Fazilati M. Comparison of fresh beef and camel meat proteolysis during cold storage. Meat Sci. 2008;80(3):892-5. https://doi.org/10.1016/j.meatsci.2008.04.007.

81. Maqsood S, Al Haddad NA, Mudgil P. Vacuum packaging as an effective strategy to retard off-odour development, microbial spoilage, protein degradation and retain sensory quality of camel meat. LWT Food Sci Technol. 2016;72:55-62. https://doi.org/10.1016/j.lwt.2016.04.022.

82. Olszewska MA, Gędas A, Simões M. Antimicrobial polyphenol-rich extracts: applications and limitations in the food industry. Food Res Int. 2020. p. 109214.

83. Djenane D, Aboudaou M, Djenane F, García-Gonzalo D, Pagán R. Improvement of the shelf life status of modified atmosphere packaged camel meat using nisin and Olea europaea subsp. laperrinei leaf extract. Foods. 2020;9(9):1336. 
84. Maqsood S, Abushelaibi A, Manheem K, Al Rashedi A, Kadim IT. Lipid oxidation, protein degradation, microbial and sensorial quality of camel meat as influenced by phenolic compounds. LWT Food Sci Technol. 2015;63(2):953-9. https://doi.org/10.1016/j.lwt.2015.03.106.

85. Shahbazi Y, Karami N, Shavisi N. Effect of Mentha spicata essential oil on chemical, microbial, and sensory properties of minced camel meat during refrigerated storage. J Food Saf. 2018;38(1):e12375.

86. Abdel-Naeem HHS, Mohamed HMH. Improving the physico-chemical and sensory characteristics of camel meat burger patties using ginger extract and papain. Meat Sci. 2016;118:52-60. https://doi.org/10.1016/j.meatsci.2016. 03.021.

87. Tang H, Darwish WS, El-Ghareeb WR, Al-Humam NA, Chen L, Zhong RM, et al. Microbial quality and formation of biogenic amines in the meat and edible offal of Camelus dromedaries with a protection trial using gingerol and nisin. Food Sci Nutr. 2020;8(4):2094-101. https://doi. org/10.1002/fsn3.1503.

88. Balamatsia CC, Paleologos EK, Kontominas MG, Savvaidis IN. Correlation between microbial flora, sensory changes and biogenic amines formation in fresh chicken meat stored aerobically or under modified atmosphere packaging at 4 C: possible role of biogenic amines as spoilage indicators. Antonie Van Leeuwenhoek. 2006;89(1):9-17. https://doi.org/10.1007/s10482005-9003-4

89. Ruiz-Capillas C, Jimenez-Colmenero F. Biogenic amines in meat and meat products. Crit Rev Food Sci Nutr. 2005;44(7-8):489-599. https://doi.org/10.1 080/10408690490489341.

90. Yehia HM, Al-Masoud AH, Elkhadragy MF, Korany SM, Nada H, Albaridi $\mathrm{NA}$, et al. Improving the quality and safety of fresh camel meat contaminated with Campylobacter jejuni using citrox, chitosan, and vacuum packaging to extend shelf life. Animals. 2021;11(4):1152. https:// doi.org/10.3390/ani11041152.

91. Gheisari HR, Eskandari M. Effect of curing on camel meat lipid oxidation and enzymatic activity during refrigerated storage. Veterinarski arhiv. 2013;83(5): 551-62.

92. Fallah AA, Tajik H, Farshid AA. Chemical quality, sensory attributes and ultrastructural changes of gamma-irradiated camel meat. J Muscle Foods. 2010;21(3):597-613. https://doi.org/10.1111/j.1745-4573.2009.00207.x.

93. Al-Bachir M, Zeinou R. Effect of gamma irradiation on microbial load and quality characteristics of minced camel meat. Meat Sci. 2009;82(1):119-24. https://doi.org/10.1016/j.meatsci.2008.12.012.

94. Kadim IT, Al-Hosni Y, Mahgoub O, Al-Marzooqi W, Khalaf SK, Al-Maqbaly RS, et al. Effect of low voltage electrical stimulation on biochemical and quality characteristics of longissimus thoracis muscle from one-humped camel (Camelus dromedaries). Meat Sci. 2009;82(1):77-85. https://doi.org/10.1016/j. meatsci.2008.12.006.

95. Kadim IT, Mahgoub O, Al-Marzooqi W, Khalaf SK, Mansour MH, Al-Sinani SSH, et al. Effects of electrical stimulation on histochemical muscle fiber staining, quality, and composition of camel and cattle Longissimus thoracis muscles. J Food Sci. 2009;74(1):S44-52. https://doi.org/10.1111/j.1750-3841.2 008.00992.x.

96. Suliman GM, Hussein EOS, Al-Owaimer AN. Improving mature camel-meat quality characteristics with calcium chloride injection. J Camel Pract Res. 2013;20(1):53-7.

97. Laranjo M, Elias M, Fraqueza MJ. The use of starter cultures in traditional meat products. J Food Qual. 2017;2017:1-18. https://doi.org/10.1155/2017/ 9546026.

98. El Adab S, Wadda WB, Tekiki A, Moussa OB, Boulares M, Sadok S, et al. Effect of mixed starter cultures on biogenic amine formation during the ripening of tunisian dry fermented camel meat sausage. Italian J Food Sci. 2020;32:2.

99. Bover-Cid S, Izquierdo-Pulido M, Vidal-Carou MC. Mixed starter cultures to control biogenic amine production in dry fermented sausages. J Food Prot. 2000;63(11):1556-62. https://doi.org/10.4315/0362-028X63.11 .1556$.

100. Melini F, Melini V, Luziatelli F, Ficca AG, Ruzzi M. Health-promoting components in fermented foods: an up-to-date systematic review. Nutrients. 2019;11(5):1189. https://doi.org/10.3390/nu11051189.

101. Ayyash M, Olaimat A, Al-Nabulsi A, Liu S-Q. Bioactive properties of novel probiotic Lactococcus lactis fermented camel sausages: cytotoxicity, angiotensin converting enzyme inhibition, antioxidant capacity, and antidiabetic activity. Food Sci Anim Resour. 2020;40(2):155-71. https://doi. org/10.5851/kosfa.2020.e1.
102. Laranjo M, Potes ME, Elias M. Role of starter cultures on the safety of fermented meat products. Front Microbiol. 2019;10:853. https://doi.org/10.33 89/fmicb.2019.00853.

103. Yarmand MS, Nikmaram P, Djomeh ZE, Homayouni A. Microstructural and mechanical properties of camel longissimus dorsi muscle during roasting, braising and microwave heating. Meat Sci. 2013;95(2):419-24. https://doi. org/10.1016/j.meatsci.2013.05.018.

\section{Publisher's Note}

Springer Nature remains neutral with regard to jurisdictional claims in published maps and institutional affiliations.
Ready to submit your research? Choose BMC and benefit from:

- fast, convenient online submission

- thorough peer review by experienced researchers in your field

- rapid publication on acceptance

- support for research data, including large and complex data types

- gold Open Access which fosters wider collaboration and increased citations

- maximum visibility for your research: over $100 \mathrm{M}$ website views per year

At BMC, research is always in progress.

Learn more biomedcentral.com/submissions 